\title{
Correspondence
}

\section{Long-term safety and efficacy of CART-20 cells in patients with refractory or relapsed B-cell non-Hodgkin lymphoma: 5-years follow-up results of the phase I and IIa trials}

Signal Transduction and Targeted Therapy (2017) 2, e17054; doi:10.1038/sigtrans.2017.54; published online 9 October 2017

For refractory or relapsed $(r / r)$ B-cell non-Hodgkin lymphoma $(\mathrm{NHL})$, the response rates to conventional salvage chemotherapy are $27-44 \%{ }^{1}{ }^{1}$ Chimeric antigen receptors (CARs) efficiently redirect T-cell specificity and cytotoxicity to cells expressing the targeted $\mathrm{Ag}$ in an HLA-independent manner. ${ }^{2}$ The early phase clinical trials of CART cells for $(r / r)$ B-cell NHL have demonstrated promising results. Recent updated data from US National Cancer Institute $(\mathrm{NCl})$ showed that five of the seven $(71 \%)$ evaluable patients with relapsed diffuse large B-cell lymphoma (DLBCL) obtained complete remissions (CRs) after infusion of anti-CD19 CAR-T cells, and four of the five CRs had long-term durability with duration ranging from 38 to 57 months. ${ }^{3}$ Encouraging results have also been seen in our prior studies of autologous CART-20 cells in patients with $\mathrm{r} / \mathrm{r}$ $\mathrm{CD} 20^{+} \mathrm{B}-\mathrm{NHL}$ (NCT01735604). ${ }^{4,5}$ This paper reports the long-term efficacy and safety of CART-20 cells in patients with $\mathrm{r} / \mathrm{r} \mathrm{CD} 2 \mathrm{O}^{+}$ B-NHL after 5-year follow-up.

From July 2012 to June 2015, a total of 17 patients with r/r B-cell $\mathrm{NHL}$ have been enrolled in our studies. As of July 2017, the median follow-up time was 20 months (range, 4-60 months). The patients underwent cytoreductive chemotherapy for tumor debulking and lymphodepletion between 3 and 7 days before T-cell infusion. All patients received at least one cycle CAR.20CD137 transduced T cells infusion at a dose of $0.5-1.5 \times 10^{7}$ $\mathrm{kg}^{-1}$. Clinical trial design and assay protocols have been reported in detail in our prior publications. ${ }^{4,5}$

The baseline characteristics of all the patients are presented in Table 1. Briefly, all patients were heavily pretreated and had received rituximab previously; 16 patients (94\%) had received 4 or more previous treatment regimens, and 12 patients $(70.6 \%)$ had relapsed after previous second-line chemotherapy regimens. One patient had relapsed post-autologous stem cell transplantation (SCT). Eleven patients (64.7\%) were defined as either refractory or progressive according to their responses to recent chemotherapeutics. Fourteen patients (82.4\%) were diagnosed with DLBCL and three (17.6\%) had indolent lymphoma. Notably, five patients had bulky tumor burden in the phase I trial.

In phase Ila trial, 11 patients were available to evaluate the objective clinical responses. The overall objective response rate was 9 of $11(81.8 \%)$, with $54.5 \%$ of patients (6/11) achieving CR and $27.3 \%(3 / 11)$ achieving partial remission (PR). One patient with PR and one patient with stable disease after CART-20 cell infusion received consolidative local radiotherapy and were subsequently converted to CR. In the phase I trial, five of six patients experienced tumor regression.

Twelve patients with remission but refusing autologous or allogeneic SCT were followed up for a median of 20 months (range, 4-60 months) from their first CART-20 cell infusion. The estimated median progression-free survival (PFS) of the 12 patients was 10 months (range, 2-57 months) (Figure 1a) and the estimated 2-year rate of PFS was $41.7 \%$ (5/12). The longest duration of response (57 months) was seen in UPNII-11

\begin{tabular}{|c|c|}
\hline Characteristic & $\begin{array}{l}\text { All patients } \\
(\mathrm{n}=17,100 \%)\end{array}$ \\
\hline Median age, years (range) & $57(25-85)$ \\
\hline \multicolumn{2}{|l|}{ Sex, no. (\%) } \\
\hline Female & $3(17.6 \%)$ \\
\hline Male & $14(82.4 \%)$ \\
\hline \multicolumn{2}{|l|}{ Disease stage } \\
\hline I, II & $4(23.5 \%)$ \\
\hline III, IV & $13(76.5 \%)$ \\
\hline \multicolumn{2}{|l|}{ IPI group } \\
\hline Intermediate: $2-3$ & 15 (88.2\%) \\
\hline High: 4-5 & $2(11.8 \%)$ \\
\hline Ki-67: Median (range), \% & 75 (60-90\%) \\
\hline BM involvement & $3(17.6 \%)$ \\
\hline Median (range) time from diagnosis, years & $3(0.25-37)$ \\
\hline $\begin{array}{l}\text { Median (range) time from last chemotherapy } \\
\text { regimen, months }\end{array}$ & $4(1-6)$ \\
\hline $\begin{array}{l}\text { Median (range) number of previous treatment } \\
\text { regimens }\end{array}$ & $7(2-14)$ \\
\hline \multicolumn{2}{|l|}{ Type of prior treatment regimen } \\
\hline One or more rituximab treatments & 17 \\
\hline Radiotherapy & 2 \\
\hline AHSCT & 1 \\
\hline \multicolumn{2}{|l|}{ Pathology, no. (\%) } \\
\hline Indolent lymphoma & $3(17.6 \%)$ \\
\hline Follicular lymphoma & $1(5.9 \%)$ \\
\hline Mantle cell lymphoma & $1(5.9 \%)$ \\
\hline Primary cutaneous marginal zone lymphoma & $1(5.9 \%)$ \\
\hline Diffuse large B-cell lymphoma & $14(82.4 \%)$ \\
\hline Relapsed after previous therapy with $\mathrm{R}-\mathrm{CHOP}$ & $1(5.9 \%)$ \\
\hline $\begin{array}{l}\text { Relapsed after previous therapy with second- } \\
\text { line chemotherapy }\end{array}$ & $12(70.6 \%)$ \\
\hline Relapsed after previous AHSCT & $1(5.9 \%)$ \\
\hline \multicolumn{2}{|l|}{ Tumor burden SPD } \\
\hline $\mathrm{SPD}>30$ & $5(29.4 \%)$ \\
\hline $\mathrm{SPD}<30$ & $12(70.6 \%)$ \\
\hline \multicolumn{2}{|l|}{ Conditioning therapy } \\
\hline None & $4(23.5 \%)$ \\
\hline FC & $1(5.9 \%)$ \\
\hline Others & $12(70.6 \%)$ \\
\hline
\end{tabular}

Abbreviations: AHSCT, autologous hematopoietic stem cell transplantation; $\mathrm{BM}$, bone marrow; $\mathrm{CHOP}$, cyclophosphamide, doxorubicin, vincristine, prednisone; FC, fludarabine and cyclophosphamide; IPI, International Prognostic Index; SPD, the sum of the products of diameters of all index lesions. Eastern Cooperative Oncology Group (ECOG) scores indicate the performance status of patients with respect to activities of daily living on a scale from 0 to 5 , with higher numbers indicating greater disability. 
a

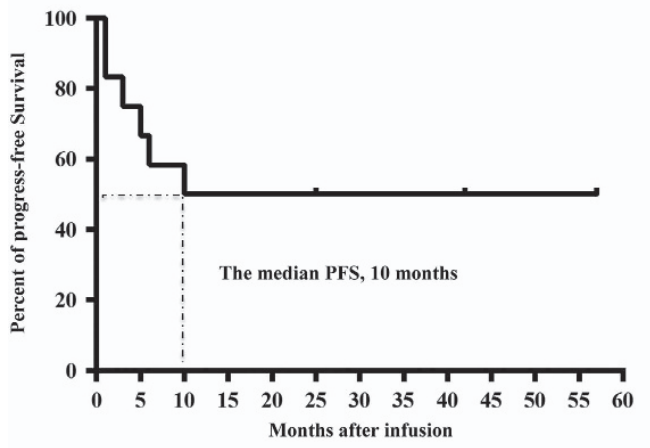

b

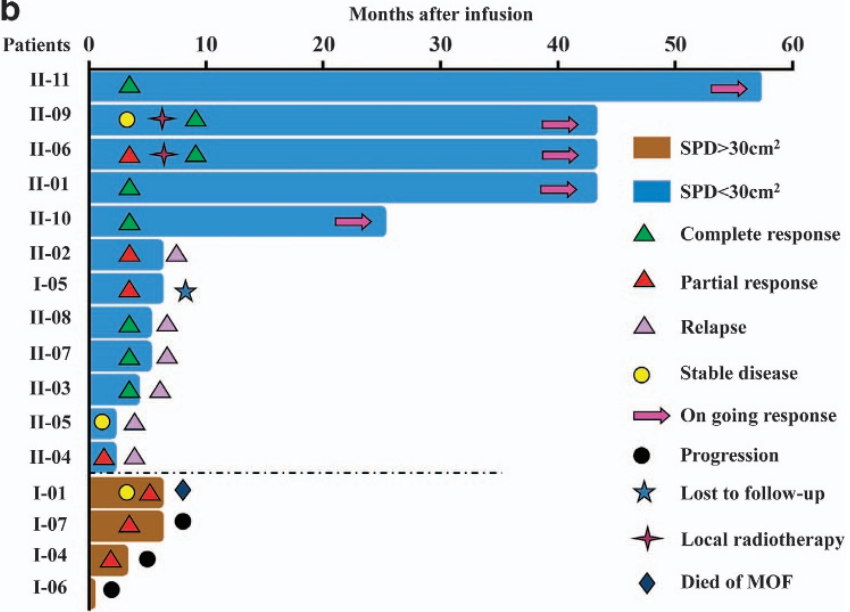

Figure 1. Kaplan-Meier curves for PFS and duration responses of all eligible patients. (a) The median PFS was 10 months (95\% Cl, 2-57 months). (b) Twelve patients with $\mathrm{SPD}<30 \mathrm{~cm}^{2}$ had clinical improvement; four patients with bulky tumors suffered lymphoma progression.

a

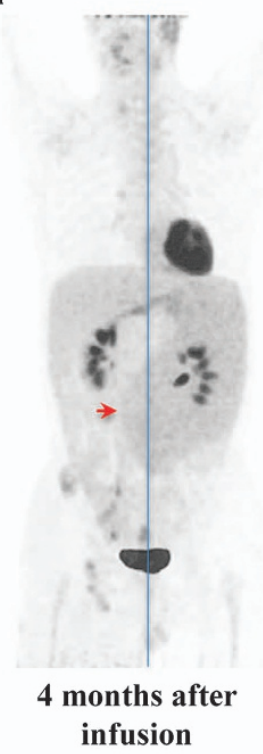

b

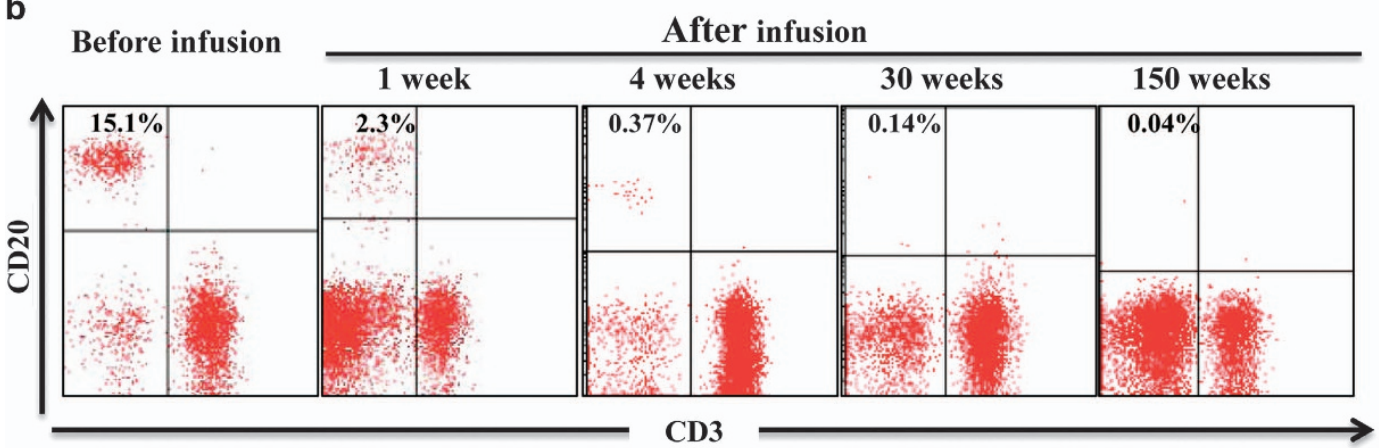

Figure 2. The change of the spleen size and CD20 $\mathrm{B}$-cell counts in the PB of patients UPNII-09. (a) The whole-body 2-[18F]-fluoro-2-deoxy-Dglucose positron emission tomography (FDG-PET) scans show the larger spleen over the midline of body at 4 months after infusion, then shrink to midline and left midline, respectively, at 12 and 24 months. Especially at 36 months after infusion, the size of spleen become almost normal. (b) The CD20 ${ }^{+}$lymphocyte cells determined by flow cytometry in PB after CART-20 cell infusion is shown. From 1 week after infusion, the proportion began to decline, and it lasted for over 150 weeks. 


\begin{tabular}{|c|c|c|}
\hline \multirow[t]{2}{*}{ Adverse events } & \multicolumn{2}{|c|}{ No. of patients $(\%, \mathrm{n}=16)$} \\
\hline & All grades & Grade $\geqslant 3$ \\
\hline \multicolumn{3}{|l|}{ Infusion-related events } \\
\hline Fever & $16(100.0 \%)$ & 0 \\
\hline Rigors & 15 (93.8\%) & $1(6.2 \%)$ \\
\hline Fatigue & $3(18.7 \%)$ & 0 \\
\hline Hypotension & $1(6.2 \%)$ & 0 \\
\hline Exudative inflammation of the lungs & $2(12.5 \%)$ & 0 \\
\hline Cytokine release syndrome & $4(25.0 \%)$ & 0 \\
\hline Acute alimentary tract hemorrhage & $2(12.5 \%)$ & $1(6.2 \%)$ \\
\hline \multicolumn{3}{|l|}{ Delayed-events after infusion } \\
\hline \multicolumn{3}{|l|}{ Hematologic events } \\
\hline Neutropenia & $3(18.7 \%)$ & $1(6.2 \%)$ \\
\hline Thrombocytopenia & $3(18.7 \%)$ & 0 \\
\hline Lymphocytopenia & $11(68.8 \%)$ & 0 \\
\hline Anemia & 2 (12.5\%) & 0 \\
\hline \multicolumn{3}{|l|}{ Immunology events } \\
\hline Serum immunoglobulin decrease & $7(43.8 \%)$ & $1(6.2 \%)$ \\
\hline Allergic reaction/hypersensitivity & $1(6.2 \%)$ & 0 \\
\hline Allergic rhinitis & $1(6.2 \%)$ & 0 \\
\hline Autoimmune enteritis & $1(6.2 \%)$ & 0 \\
\hline Vasculitis & $1(6.2 \%)$ & 0 \\
\hline Herpes zoster & $1(6.2 \%)$ & $1(6.2 \%)$ \\
\hline Viral hepatitis & 0 & 0 \\
\hline Other virus infection & $1(6.2 \%)$ & 0 \\
\hline Dermatomycoses & $1(6.2 \%)$ & 0 \\
\hline Bacterial infection & $1(6.2 \%)$ & 0 \\
\hline \multicolumn{3}{|l|}{ Nervous system disorder } \\
\hline Numbness & $1(6.2 \%)$ & 0 \\
\hline Insomnia & $1(6.2 \%)$ & 0 \\
\hline Hypomnesis & $1(6.2 \%)$ & 0 \\
\hline \multicolumn{3}{|l|}{ Laboratory abnormalities } \\
\hline ALT elevation & $2(12.5 \%)$ & 0 \\
\hline AST elevation & $1(6.2 \%)$ & 0 \\
\hline Hyperuricaemia & $2(12.5 \%)$ & 0 \\
\hline Hypoalbuminaemia & $1(6.2 \%)$ & 0 \\
\hline Hypokalemia & $1(6.2 \%)$ & 1 \\
\hline LDH elevation & $2(12.5 \%)$ & 0 \\
\hline
\end{tabular}

(Figure 1b). The UPNII-09 with advanced refractory marginal zone lymphoma had achieved remission of skin and bone marrow after the first CART-20 cell infusion, but still had enlarged spleen. Thus, UPNII-09 received the consolidated second infusion, and the size of the spleen became gradually smaller and continued to shrink for up to 36 months (Figure 2a). B-cell aplasia of this patient sustained for 150 weeks (Figure $2 \mathrm{~b}$ and Supplementary Figure).

The treatment regimen was generally well tolerated. The acute adverse events included temporary chills and fever. The long-term monitoring for adverse events was for 5 years. The delayed adverse events related to CART-20 therapy were summarized in Table 2. No Grade 4 toxicities were observed. Grade 3 herpes zoster due to long-term hypogammaglobulinemia was observed in UPNII-09 at 7 months after infusion. The decrease of immunoglobulin occurred in all patients with B-cell lack. We preventatively administered intravenous immunoglobulin to avoid hypogammaglobulinemia until the B-cell recovery. During the long follow-up periods, no patient was found to have susceptibility to viral infection or increase of other diseases incidence.

Some similar studies of CART cell therapy of B-cell NHL have been reported since 2001. ${ }^{6,7}$ At the 2016 annual meeting of the
American Society of Hematology, updated data from Transcend $\mathrm{NHL} 001$ trial showed that the longest observable PFS of patients with DLBCL was 9 months in those who achieved CR after treatment with CART-19 cells. ${ }^{8}$ However, in our trials, the longest continued complete remission time of a patient with DLBCL was 57 months, which was comparable to the updated data from $\mathrm{NCl}$ group's trial of CART-19 in DLBCL. ${ }^{3}$

In conclusion, long-duration CRs were observed in our CART-20 cell therapy. Compared to the outcomes of other clinical trials evaluating CAR-T cells in $\mathrm{r} / \mathrm{r}$ B-NHL, our CART-20 cell therapy possibly made patients get longer PFS time. Our results provided unique evidence supporting the efficacy and safety of CART-20 in patients with $r / r$ B-cell NHL.

\section{COMPETING INTERESTS}

The authors declare no conflict of interest.

\section{ACKNOWLEDGEMENTS}

This study was supported by grants from the National Natural Science Foundation of China (No. 81402566), the grants the Science and Technology Planning Project of Beijing City (No. Z151100003915076 to WDH) and the National Key Research and Development Program of China (No. 2016YFC1303501 and 2016YFC1303504 to WDH).

\section{AUTHOR CONTRIBUTIONS}

$W Y Z, Y L$ and $Y W$ designed and performed the in vitro experiment, analyzed data and wrote the manuscript; CMW ensured compliance with regulatory requirements for the clinical trial; QMY supervised the manufacture of cells in infusion; WDH and HLZ enrolled patients in the study, analysis data and wrote and reviewed the manuscript.

Wen-ying Zhang ${ }^{1,4}$, Yang Liu ${ }^{2,4}$, Yao Wang ${ }^{3,4}$, Chun-meng Wang ${ }^{1}$, Qing-ming Yang ${ }^{1}$, Hong-li Zhu ${ }^{2}$ and Wei-dong Han ${ }^{1,3}$

${ }^{1}$ Biotherapeutic Department, Chinese PLA General Hospital, Beijing,

China;

${ }^{2}$ Department of Geriatric Hematology, Chinese PLA General Hospital, Beijing, China and

${ }^{3}$ Department of Immunology, Institute of Basic Medicine, School of Life Sciences, Chinese PLA General Hospital, Beijing, China Correspondence: W-d Han or H-I Zhu (hanwdrsw@sina.com or bjzhuhl301@vip.sina.com) ${ }^{4}$ These authors contributed equally to this work.

\section{REFERENCES}

1 Pettengell R, Sebban C, Zinzani PL, Derigs HG, Kravchenko S, Singer JW et al. Monotherapy with pixantrone in histologically confirmed relapsed or refractory aggressive B-cell non-Hodgkin lymphoma: post-hoc analyses from a phase III trial. Br J Haematol 2016; 174: 692-699.

2 Wang Z, Guo Y, Han W. Current status and perspectives of chimeric antigen receptor modified T cells for cancer treatment. Protein Cell 2017; e-pub ahead of print 2 May 2017; doi: 10.1007/s13238-017-0400-z.

3 Kochenderfer JN, Somerville RPT, Lu T, Yang JC, Sherry RM, Feldman SA et al. Longduration complete remissions of diffuse large B-cell lymphoma after anti-CD19 chimeric antigen receptor therapy. Mol Ther 2017; e-pub ahead of print 21 July 2017; doi: 10.1016/j.ymthe.2017.07.004.

4 Wang Y, Zhang WY, Han QW, Liu Y, Dai HR, Guo YL et al. Effective response and delayed toxicities of refractory advanced diffuse large B-cell lymphoma treated by CD20-directed chimeric antigen receptor-modified T cells. Clin Immunol 2014; 155: 160-175.

5 Zhang W-Y, Wang Y, Guo Y-L, Dai H-R, Yang Q-M, Zhang Y-J et al. Treatment of CD20directed chimeric antigen receptor-modified $T$ cells in patients with relapsed or refractory B-cell non-Hodgkin lymphoma: an early phase lla trial report. Signal Transd Target Ther 2016; e-pub ahead of print 11 March 2016; doi: 10.1038/sigtrans.2016.2.

6 Ghetie MA, Bright H, Vitetta ES. Homodimers but not monomers of Rituxan (chimeric anti-CD20) induce apoptosis in human B-lymphoma cells and 
synergize with a chemotherapeutic agent and an immunotoxin. Blood 2001; 97: 1392-1398.

7 Till BG, Jensen MC, Wang J, Qian X, Gopal AK, Maloney DG et al. CD20-specific adoptive immunotherapy for lymphoma using a chimeric antigen receptor with both CD28 and 4-1BB domains: pilot clinical trial results. Blood 2012; 119: 3940-3950.

8 Abramson JS, Palomba L, Gordon LI, Lunning M, Arnason J, Forero-Torres A et al. Transcend NHL 001: Immunotherapy with the CD19-Directed CAR T-Cell Product JCAR017 Results in High Complete Response Rates in Relapsed or Refractory B-Cell Non-Hodgkin Lymphoma. Blood 2016; 128: 4192-4192.
This work is licensed under a Creative Commons Attribution 4.0 International License. The images or other third party material in this article are included in the article's Creative Commons license, unless indicated otherwise in the credit line; if the material is not included under the Creative Commons license, users will need to obtain permission from the license holder to reproduce the material. To view a copy of this license, visit http://creativecommons.org/licenses/ by/4.0/

(c) The Author(s) 2017

Supplementary Information accompanies the paper on the Signal Transduction and Targeted Therapy website (http://www.nature.com/sigtrans) 